\title{
Official Language Bilingualism for Allophones in Canada: Exploring Future Research
}

\section{Callie Mady and Miles Turnbull}

This article offers a review of policy and research as they relate to Allophones and their access to French Second Official Language (FSOL) programs in Englishdominant Canada. Possible areas of future research are woven throughout the review as questions emerge in the summary of relevant literature.

Notre article comprend une recension des documents de politique et des projets de recherche concernant les Allophones inscrits aux programmes de français langue seconde et officielle (FLSO) au Canada. Tout au long de l'article, nous tissons une série de questions de recherche possible pour le futur comme elles ont émergé pendant le développement de la recension des écrits.

The Canadian Constitution (Canada, Department of Justice, 1982) guarantees equal status to English and French as the official languages of Canada providing for federal government services in both languages. As such, many federal job opportunities at minimum are centered on official-language bilingualism. In addition to linguistic considerations, the federal government recognizes official-language bilingualism as vital to Canadian identity (Office of the Commissioner of Official Languages, 2006). The dual privileging of English and French by way of commodity and identity (Heller, 2002), then, encourages immigrants to Canada to consider such proclamations as they establish themselves and reconstruct their identities (Blackledge \& Pavlenko, 2001).

As Canada moves forward with its agenda to promote linguistic duality and official-language bilingualism, it must consider the effect of the growing Allophone population. In 2000, former Commissioner of Official Languages Dyane Adam called for a clear research agenda relating to Allophones and language education in Canada; she recognized immigration as a challenge to official-language bilingualism (Office of the Commissioner of Official Languages, 2000). This challenge continues to grow, as immigration is the most significant factor accounting for growth in the Canadian population; recent immigration has accounted for two thirds of Canada's population growth, and about 90\% (Canadian School Boards Association, 2006; Ontario Public School Boards, 2005) of these immigrants come from countries where neither French nor English is the first language; a clear research agenda has yet to be identified. 
Although acquiring French Second Official Language (FSOL) in Englishdominant regions of Canada may not be an immediate concern for some new Canadians facing challenges such as stresses related to settlement, trauma caused by war or significant strife, educational gaps and English acquisition (Coelho, 2004), research indicates that some Allophones do desire to learn French as well as English to expand their multilingual identities and to optimize their economic and sociocultural opportunities as they settle in Canada (Dagenais, 2003; Parkin \& Turcotte, 2003). A desire to learn Canada's two official languages may be grounded in immigrants' pursuit of greater economic well-being (Picot \& Sweetman, 2005) and a stronger sense of belonging (Burton \& Phipps, 2010). They may seek to take advantage of the benefits attributed to official-language bilingualism by the federal government. It is, therefore, incumbent on researchers to gain a better understanding of the complexities of Allophones' presence in FSOL programs.

The goal of this article is, therefore, to propose possible avenues for future research related to Allophones and FSOL programming in Canada. ${ }^{1}$ We begin with a synthesis of relevant research studies that have examined Allophones in FSOL programs. The research is organized into four categories: (a) implementation of policy; (b) teachers' and principals' perspectives; (c) motivation to study FSOL; and (d) achievement in FSOL. Possible areas of future research ${ }^{2}$ are woven throughout the review as questions emerge from the summary of the literature.

Before moving to a review of earlier research, however, we begin by offering definitions of the terms that we use throughout the article.

\section{Definitions}

For the purpose of this article, Allophones is used to refer to immigrants who are English-language learners living in English-dominant Canada. Their first language is neither French nor English. Immigrant is used to refer to a person who is or has been a landed immigrant. FSOL refers to French instruction to Allophones living in English-dominant Canada. Core French refers to a nonintensive model for French instruction where learners receive short periods of French instruction. Intensive French refers to an FSOL delivery format that offers learners a concentrated exposure to French involving an increase in the allocated hours; students typically complete $70 \%$ of the school day in French over one semester (grades 5 or 6).

\section{Methodology}

In preparation for this article, we conducted database searches of Education Resources Information Center (ERIC), Education Research Complete, and PsycINFO for recent scholarly articles and reports. We read and reviewed recently published books (from 2000 to the present). We then grouped data into the four thematic categories used to organize this article. 


\section{Earlier Research}

Implementation of Policy: Allophones' Access to FSOL Programming?

Research into the implementation of provincial language policies has revealed a variety of practices to do with the inclusion of Allophone students in the study of FSOL. Taaffe, Maguire, and Pringle (1996) and Mady (2006, 2010), for example, provide evidence that although French is a compulsory subject in Ontario, Allophone students are at times excluded from FSOL programs. In their three-year longitudinal study of additional language education for minority children, Taaffe et al. unveiled a variety of practices regarding the inclusion of Allophone students in the study of French in Ottawa and Montreal. The practices ranged from withdrawal of Allophone students from FSOL to insistence that all students attend FSOL classes. Where Allophone students participated in core French, Taaffe et al. found that they performed as well as their Anglophone peers. Similarly, Mady (2006), in a survey of principals and guidance department heads of a large urban school board in Ontario, found that none of the secondary schools offered FSOL to all their Allophone students. Most of the participants (54\%) reported that they never allowed Allophone students to study FSOL, whereas the remaining $46 \%$ stated that Allophone students would sometimes be included in FSOL. Where Allophone students were included in FSOL, the administrators recognized that they performed at least as well as their Canadian-born peers. Similarly, although most Allophone parents interviewed in Mady's (2010) study recognized their children's ability to learn FSOL, some encountered difficulty when attempting to register their children in intensive FSOL learning opportunities. These research results, from a province with a large number of immigrants, where French is mandatory from grades 4-9, provide evidence that exclusionary practices create obstacles for Allophone students who wish to learn their second official language (Mady, 2012). However, additional research conducted in other contexts across Canada would help to clarify more fully the question of access, the implementation of policy, and the mitigating factors. Thus we propose that future research address the following issues.

1. What factors influence provincial language policy development?

2. How do policymakers, parents, teachers, and administrators view current provincial language policies and make decisions about the integration or exclusion of Allophones in FSOL programming in Canada?

3. How does federal policy affect policy and practice in the provinces and territories in terms of Allophones' access to FSOL education?

4. How do the changing demographics and increasing diversity of Canada affect language planning in Canada?

5. What factors influence Allophones' readiness to study FSOL? How do these factors influence decisions to include allophones in FSOL programming? 


\section{Teachers' and Principals' Perspectives on FSOL and Allophones}

Research on teachers' perspectives on the inclusion of Allophone students in FSOL classes adds more evidence that Allophone students encounter obstacles when their official-language bilingualism is at stake. Many FSOL teachers have questioned the inclusion of Allophone students in their classes. In fact, Calman and Daniel (1998) were asked to expand their review of core French in the former North York Board of Education to collect and review data on Allophone students' French acquisition in response to teachers' concerns about the integration of Allophones in core French. Teachers cited Allophone students' difficulties in participating orally in French, completing their assigned French work, writing in French, and catching up to their peers' level of the language. Some school principals interviewed by Calman and Daniel expressed concern that French was a burden for Allophone students. However, the results of French testing in the study showed that these students' performance did not differ significantly from that of "regular" students, although they had been exposed to much less French instruction than the Canadian-born students.

Lapkin, Macfarlane, and Vandergrift's (2006) survey of 1,305 FSOL teachers across Canada revealed similar beliefs among FSOL teachers. In one of the two open-ended questions on a Web-based questionnaire, the teachers responding revealed that dealing with diversity in their classrooms was their greatest challenge, specifically highlighting Allophone students as one source of the diversity.

Teachers and principals can either open doors to the opportunities of official-language learning or create barriers to this learning. More research is needed to understand these key stakeholders' beliefs and attitudes. Moreover, the few studies that exist have almost all been completed in Ontario or in larger urban centers where many immigrants live. Additional research is required in many areas of Canada. The following questions may stimulate some of this work.

1. What do school administrators believe about Allophones and their inclusion in FSOL programs?

2. What do FSOL teachers believe about Allophone students? How do they perceive Allophones? Why?

3. How do English-as-a-second-language teachers view Allophones' acquisition of FSOL in English-dominant Canada?

4. How do FSOL teachers' own language-learning experiences affect their beliefs about the inclusion of Allophone students in FSOL? How do internationally educated teachers' beliefs compare with those of teachers educated in Canada?

5. How can successful Allophones serve as models and motivation for Anglophone students to be more successful in FSOL? 
6. How do factors such as educational and language background, country of origin, psychological assessment, socioeconomic status, age, and FSOL program affect decisions about inclusion/exclusion of Allophones in FSOL and modification of their programming when included?

\section{Allophone Students' Motivation to Learn French}

Three studies examined Allophone students' motivation to study French in Canada. First, through interviews with three Indo-Pakistani families, Dagenais and Berron $(1998,2001)$ found that these families were motivated to have their children learn both of Canada's official languages: so motivated in fact that they enrolled them in French immersion in British Columbia. The parents' motivation was grounded in their own prior exposure to the multilingual context in Asia and their confidence in their children's ability to learn more than one language. These parents also recognized the advantages of children for learning French: their age and their experience with languagelearning. In addition, the parents acknowledged the need to seek out French learning opportunities because English is so dominant and accessible in Canada. They saw such opportunities as a means for their children to have the same advantages as those from the majority community.

Second, Mady (2003) compared Allophone students' and Canadian-born English-speaking students' motivation to study French. One hundred and one students in three grade 9 French programs (academic, applied, or introductory French for Allophone students) completed questionnaires. Allophone students, most from India, responded more positively than the Canadian-born students on 16 of the 21 variables in the survey. The Allophone students were significantly more motivated to study French than the grade 9 applied students, whereas there was no statistical difference between the Allophones and the grade 9 academic students. Follow-up interviews, however, revealed that the Allophone students were indeed more motivated to study French than their Canadian-born peers. The Allophone students were willing to invest in learning French in the hope of developing a true Canadian identity, which according to them, involved learning French. The Allophone students expressed the returns on their investment in languagelearning in terms of citizenship and access to better jobs.

Third, Mady (2006) examined Allophone students' journals ( $\mathrm{N}=17$ ) in which they recorded their perceptions of studying French in Canada while living in southern Ontario. All the participants expressed confidence in their ability to learn French. Also noteworthy is the participants' view of their English and French competence. For example, a repeated theme in the participants' journals revealed satisfaction with their abilities in both French and English despite their limited proficiency. Although not stated explicitly, such accounts give the impression that these participants' definition of multilingualism is the ability to communicate functionally in several languages 
rather than to attain native-like mastery in any language. The Allophone participants' comments indicating that learning French was easy for them suggest that these members of diverse communities view official-language bilingualism as an opportunity (rather than an obstacle to overcome).

The three studies mentioned above have drawn on more traditional notions of motivation in second-language learning. However, Norton (2000) has proposed a significantly different perspective on the concept of learner motivation and second-language learning that clashes somewhat with traditional theories of motivation.

To explain the variability in learners' success in language-learning, Norton (2000) introduced the concept of investment to describe the relationship of second-language learners to the target language and its culture. Norton introduced the term investment in relation to second-language learning after studying immigrant women from various backgrounds for whom the earlier theories on second-language learners' motivation were inadequate to explain their language-learning experiences and engagement to learn English. The women in Norton's study lacked confidence and had high anxiety, but were still highly motivated. Norton argued that the existing theories of secondlanguage learners' motivation focused solely on the individual's responsibility for making progress in acquiring a language. Norton argues that these theories ignore the influence of inequitable relations of power between language-learners and target-language speakers. Somewhat similarly, the research examining Allophones studying FSOL depicts Allophones who invest in learning French despite the obstacles. These learners' potential return on their investment consists of a reconstructed identity, academic success, greater job opportunities, and stability.

The anticipation of a return on their FSOL learning investment is clear in the following studies that examined Allophones' perceptions about officiallanguage bilingualism in western Canada. Dagenais and Jaquet (2000) interviewed 12 Asian families whose children were enrolled in French immersion in western Canada. Through semistructured interviews, they determined that the Allophone parents chose French immersion for their children while maintaining their home language with a view to adding to their already multilingual identities and thus better integrating into the Canadian context. In a further examination of the same data, Dagenais (2003) showed that the Allophone families chose for their children to be enrolled in French immersion while maintaining their home language in the hope of providing them with access to Canada's official-language communities and greater job opportunities. In a later examination of the same interviews, Dagenais and Moore (2008) revealed that the parents' conscious decision to have their children in French immersion was grounded not only in the parents' confidence in their children's abilities, but also in the hope of their children adding Canadian to the configuration of their identities. 
The future research issues that we propose should lead to a greater understanding of the multiple factors that lead to Allophones' motivation to learn FSOL.

1. What are the characteristics of successful Allophone learners of FSOL?

2. How do Allophone students' motivations and investments change over time?

3. Does a novelty effect influence Allophones' initial success and interest in French?

4. What are the links between Allophone students' beliefs, attitudes about language-learning, motivation, and actions?

5. How do Allophone students view official-language bilingualism?

\section{Research on Achievement in French}

In addition to providing evidence that Allophone students wish to study French, the following seven studies, three in core French and four in immersion, reveal that Allophone students are successful in FSOL.

\section{Studies in Core French}

Three Canadian studies examined Allophone students' achievement in core French: two at the elementary level and one at secondary. First, in Calman (1988) compared the French listening comprehension of grade 8 Allophone students with that of their Canadian-born peers. Calman found no significant difference between the two groups, although the Canadian students had three more years of French experience. Second, Carr (2007) compared two groups of grade 5 Allophone students' (one in intensive French, the other in the regular English stream) performance in English. Results indicated a significant difference in oral language and broad language ability in favor of the Allophone students in the intensive French program compared with their peers in the mainstream English program. Third, Mady (2006) compared the French proficiency of Allophone students with that of their Canadian-born peers in grade 9 using a multi-skills test. The comparisons revealed that the Allophone students, most of whom were south Asian, outperformed the Canadian-born participants on one of two writing components, as well as both the listening and reading sections of the test, despite five years less exposure to French and with no correlations with socioeconomic status.

\section{Studies in French Immersion}

Similar to the studies in core French, the five Canadian studies described here reveal that Allophone students outperform their peers in French immersion. First, in their study of middle French immersion students, Hart, Lapkin, and Swain (1988) found that students from homes where neither official language was spoken outperformed students from English first-language homes on a multi-skills French test on all measures except a fluency rating, with students from Romance-language backgrounds outperforming those from non- 
Romance-language backgrounds. They also discovered a correlation between test scores and the frequency of non-official-language use in the home; the more the non-official first language was used in the home, the higher the students' French test scores. Second, after further analysis of these same data, Swain et al. (1990) discovered that literacy in the non-official language correlated positively with learning French.

Third, Bild and Swain (1989) used two oral and two written tests to compare the French proficiency of students from three language backgrounds: an English-speaking group, an Italian-speaking group, and a heterogeneous non-Romance first-language group. Data gathered from the French tests revealed that the two multilingual groups outperformed the English-speaking group. Like other authors, Bild and Swain found a positive correlation between continued study of the first language and French proficiency (for the multilingual students).

Fourth, Taylor (1992) examined French and math test results of an elementary Allophone Cantonese child in French immersion. This student performed at or above the class average in all but a word identification section of the French tests administered to a group of early French-immersion students.

Although Allophone students' achievement in French has been investigated more than any other research issue in this area, more work is needed to understand better how and why Allophones meet, or do not meet, with success in Canadian FSOL programs. We propose the following questions for consideration.

1. How do Allophone students perform on large-scale testing that assesses French-language skills (compared with those of Anglophone peers)?

2. How well do Allophones perform in English and other school subjects when they are enrolled in French immersion and intensive French?

3. How does the Allophones' learning of FSOL affect their learning of English and vice versa?

4. How does Allophones' proficiency in their first language, in other Romance and non-Romance languages, and in English affect their learning of FSOL?

5. How does Allophones' achievement in core French change over time?

\section{Discussion}

Parts of this section are drawn from a paper by Mady previously commissioned by Canadian Parents for French and used with their permission. Canadian educators have a moral and ethical responsibility to ensure that all Canadians have equitable access to studying both Canada's official languages. Denying Allophones access to FSOL programs denies them important capital for achieving success in Canadian schools and in society. To increase Allophones' access to and success in FSOL programming, and by so doing to support Canadian government initiatives and goals related to 
linguistic duality and official bilingualism, research is urgently needed that adopts an open-minded position that frames official-language bilingualism for Allophones as an opportunity for all rather than a challenge or obstacle. Research shows that it can be beneficial for Allophone students to have access to FSOL learning. Access to second official-language training responds to the immigrant communities' own desires to become bilingual in both official languages (Dagenais \& Berron, 2001; Mady, 2003; Mady \& Turnbull, 2007; Parkin \& Turcotte, 2003). In addition, such occasions allow Allophones to profit from the benefits of official-language bilingualism in Canada, allowing them to participate fully in society. In addition to future opportunities, research shows that Allophones can be successful in FSOL programs although they may have difficulty in other areas of the school curriculum (Mady, 2006). The success of Allophone students in learning French, which is not dependent on English, may therefore provide a means for school communities to address the failure of minority students to succeed academically (Ontario Ministry of Education, 1994). Not only do Allophone students meet with success in studying French, but a more intensive exposure to French can also enhance their English skill development (Carr, 2007). Last, access to FSOL learning provides Allophone students with access to teachers who understand their language-learning needs and are prepared to meet them. ${ }^{3}$

In addition to the potential benefit for students, inclusion of Allophones in second official-language learning can also support government initiatives: (a) providing Allophones with opportunities to learn their second official language supports the federal government's obligation and desire to enhance the use of French and English in Canada; (b) providing second official-language learning opportunities for Allophones upholds the federal government's commitment to promote linguistic duality; and (c) such opportunities provide support to federal government policy. The Action Plan for Official Languages in Canada (2003) and the subsequent Roadmap for Canada's Linguistic Duality 2008-2013 (Department of Canadian Heritage, 2008), for example, recognize that education is one way to make the two official languages available to all Canadians. However, the current state of research related to FSOL education for Allophones is in its infancy. Moreover, most of the research that has been conducted thus far has occurred in large urban centers where many Allophones live. However, immigration patterns are shifting. Smaller areas of the country are also facing challenges when Allophones arrive in significantly different contexts. Moreover, we believe that many stakeholders in Canadian education are unaware of the policy issues or research that we present in this article. Information needs to be disseminated in order to dispel common myths associated with learning additional languages so that decisions to exclude Allophones from official-language learning can be based on well-grounded knowledge. To 
achieve these goals, however, additional research is necessary to convince certain stakeholders that a convergence of linguistic duality with cultural diversity is beneficial to all Canadians.

Finally, we acknowledge that not all immigrants are alike; there may in fact be good reason for excluding some of them from FSOL. The research questions we propose above leave room for identifying individual differences among immigrant children and for understanding this complex issue, which relates not only to official-language learning, but also to national unity and harmony. We hope that this article will contribute to further debate, renewal, and crucial future research.

\section{Notes}

${ }^{1}$ We acknowledge two research agendas developed by Lapkin, Swain, and Shapson (1990) and Lapkin, Harley, and Taylor (1993). This article is inspired by these excellent contributions to French-as-a-second language education in Canada. However, our context is quite different, and the body of research from which we build is much less developed than that with which Lapkin et al. (1990) and Lapkin et al. (1993) were working.

2 These issues will inevitably be addressed from varied theoretical frameworks and methodological approaches for a variety of purposes: large-scale projects conducted by university scholars, graduate students for master's theses and doctoral dissertations, professional associations that sponsor relevant research projects, teachers who conduct action research projects in their classrooms, or educational contexts. It is, therefore, impossible for us to assign a relative importance or priority to the issues that we identify. Researchers will make these decisions in their own contexts.

${ }^{3}$ Simons and Connelly (2000) claim that the failure of many Allophone students is in part due to classroom teachers who do not understand second-language development and so are not able to meet the needs of language-learners.

\section{Acknowledgments}

We are grateful to Sharon Lapkin and Michael Salvatori, whose constructive feedback helped improve this article. We are also grateful to SSHRC and Canadian Heritage for the funding that supported the development of this article.

\section{The Authors}

Callie Mady is an associate professor at the Schulich School of Education of Nipissing University. She is the author of numerous academic articles on FSL and co-author of several FSL classroom resources. As it pertains to ESL, Callie was an ESL teacher, department head, and head of a reception center.

Miles Turnbull is Dean (Interim) and a professor in the Faculty of Education at the University of Prince Edward Island. He works in the preservice program in French second-language teaching, in the MEd program in leadership and learning, and the PhD program in educational studies.

\section{References}

Bild, E., \& Swain, M. (1989). Minority language students in a French immersion program:

Their French proficiency. Journal of Multilingual and Multicultural Development, 10, 255-274.

Blackledge, A., \& Pavlenko, A. (2001). Negotiation of identities in multilingual contexts. International Journal of Bilingualism, 5, 243-257. 
Burton, P., \& Phipps, S. (2010, August). The well-being of immigrant children and parents in Canada. Paper presented at the 31st general conference of the International Association for Research in Income and Wealth, St. Gallen, Switzerland.

Calman, R. (1988). Core French program review: Grades 3-8: Technical report. North York, ON: North York Board of Education.

Calman, R., \& Daniel, I. (1998). A board's eye view of core French: The North York Board of Education. In S. Lapkin (Ed.), French second language education in Canada: Empirical studies (pp. 283-325). Toronto, ON: University of Toronto Press.

Canada, Department of Justice. (1982). Constitution Act 1982. Available: http:/ /lawslois.justice.gc.ca/eng/Charter/

Canada, Privy Council Office. (2003). The next act: New momentum for Canada's linguistic duality. Available: http://www.cpfnb.com/articles/ActionPlan_e.pdf

Canadian School Boards' Association. (2006). Canadian school boards association consultation paper on meeting the language learning and settlement needs of immigrant children and youth in Canada's school systems. Available: http://www.opsba.org/index.php?q=system/files/CSBA_Draft_Consultation_SLL.pdf

Carr, W. (2007). ESL testing of intensive French students Unpublished doctoral dissertation, Simon Fraser University.

Coelho, E. (2004). Adding English: A guide to teaching in multilingual classrooms. Toronto, ON: Pippin.

Dagenais, D. (2003). Accessing imagined communities through multilingualism and immersion education. Journal of Language, Identity and Education, 2, 269-283.

Dagenais, D., \& Berron, C. (1998). A case study of multilingualism and educational choices in immigrant families. Vancouver, BC: Simon Fraser University (RIIM Working Papers).

Dagenais, D., \& Berron, C. (2001). Promoting multilingualism through French immersion and language maintenance in three immigrant families. Language, Culture and Curriculum, 14(2), 142-155.

Dagenais, D., \& Jaquet, M. (2000). Valorisation du multilinguisme et de l'education bilingue dans des familles immigrantes. Journal of International Migration and Integration, 1, 389-404.

Dagenais, D., \& Moore, D. (2008). Représentations des littératies plurilingues, de l'immersion en français et des dynamiques identitaires chez des parents chinois. Canadian Modern Language Review, 65, 11-31.

Department of Canadian Heritage. (2008). Roadmap for Canada's linguistic duality 2008-2013: Acting for the future. Available:

http://www.pch.gc.ca/slo-ols/pubs/08-13-LDL/index-eng.cfm

Hart, D., Lapkin, S., \& Swain, M. (1988). Ethnolinguistic minorities: Tracking success in an exemplary English-French immersion program. Toronto, ON: MLC, OISE/UT.

Heller, M. (2002). Globalization and the commodification of bilingualism in Canada. In D. Block \& D. Cameron (Eds.), Globalization and language teaching (pp. 47-67). London: Routledge.

Lapkin, S., Harley, B., \& Taylor, S. (1993). Research directions for core French in Canada. Canadian Modern Language Review, 49, 476-513.

Lapkin, S., Macfarlane, A., \& Vandergrift, L. (2006). Teaching French in Canada: FSL teachers' perspectives. Ottawa: Canadian Teachers' Federation.

Lapkin, S., Swain, M., \& Shapson, S. (1990). French immersion research agenda for the 90s. Canadian Modern Language Review, 46, 639-673.

Lapkin, S., Vandergrift, L., \& Macfarlane, A. (2005). National survey of FSOL teachers. Ottawa: Canadian Association of Second Language Teachers.

Mady, C. (2003). Motivation to study and investment in studying core French in secondary school: Comparing English as a second language students and Canadian-born students. Unpublished master's thesis, Ontario Institute for Studies in Education, University of Toronto. 
Mady, C. (2006). The suitability of core French for recently arrived English-as-a-second-language adolescent immigrants. Unpublished doctoral dissertation, Ontario Institute for Studies in Education, University of Toronto.

Mady, C. (2007). New Canadians in FSOL programs: An untapped resource. Final report submitted to the Department of Canadian Heritage, one component of the SSHRC Virtual Scholar program entitled The socio-cultural and socio-political realities of French second language education in Canada.

Mady, C. (2010). Voices of allophone adults and allophone university students: Perspectives and experiences with French as a second official language in Canada. Ottawa: Canadian Parents for French.

Mady, C. (2012). Official language bilingualism to the exclusion of multilingualism: Immigrant student perspectives on French as a second official language in "Englishdominant" Canada. Language and Intercultural Communication, 12(1), 74-89.

Mady, C., \& Turnbull, M. (2007). Allophones in FSL programs: An untapped resource. In M. Turnbull (Ed.), The socio-cultural and socio-political realities of French second language education in Canada (pp. 1-29). Ottawa: University of Ottawa Press.

Norton, B. (2000). Identity and language learning: Gender, ethnicity, and educational change. Harlow, UK: Pearson Education.

Norton Peirce, B. (1995). Social identity, investment, and language learning. TESOL Quarterly, 29, 9-31.

Office of the Commissioner of Official Languages. (2000). Annual Report 1999-2000. Ottawa: Queen's Printer.

Office of the Commissioner of Official Languages. (2006). Annual Report 2005-2006. Ottawa: Queen's Printer.

Ontario Ministry of Education. (1994). For the love of learning: Report of the Royal Commission on Learning. Toronto, ON: Publications Ontario.

Ontario Public School Boards' Association. (2005). Position paper on second language learning in Ontario. Available:

http://www.opsba.org/index.php?q=system/files/SecondLanguageLearning_PositionP aper.pdf

Parkin, A., \& Turcotte, A. (2003, May). Public support for bilingualism in Canada. Paper presented at the annual conference of the Royal Commission on Bilingualism and Biculturalism: 40 Years Later, Montreal.

Picot, G., \& Sweetman, A. (2005). The deteriorating economic welfare of immigrants and possible causes: Update 2005. Statistics Canada Catalogue No. 11F0019MIE. Ottawa. Analytical Studies Branch Research Paper Series.

Simons, J., \& Connelly, M. (2000). Quality ESL programs. Lanham, MD: Scarecrow Press.

Swain, M., Lapkin, S., Rowen, N., \& Hart, D. (1990). The role of mother tongue literacy in third language learning. Journal of the Australian Advisory Council on Languages and Multicultural Education, 4, 111-121.

Taaffe, R., Maguire, M., \& Pringle, I. (1996). The impact of social contexts and educational policy/practice on biliteracy development: Ethnolinguistic minority children in English primary schools in Ottawa and Montreal. Journal of the CAAL, 8(2), 85-101.

Taylor, S. (1992). Victor: A case study of a Cantonese child in early French immersion. Canadian Modern Language Review, 48, 736-759. 